\title{
ECONOMIC EFFECTS OF TOURISM ON THE WORLD ECONOMY
}

\author{
Miloš Pjanićc ${ }^{1}$ (i)
}

DOI: https://doi.org/10.31410/tmt.2019.291

\begin{abstract}
Along with the globalization of the world economy, there is a globalization of the tourism industry, having a significant impact on the growth of international tourism worldwide. Tourism is one of the key factors for the growth and development of the world economy and at the same time the new export industry. Tourism development is a significant source of foreign exchange, influences employment growth, growth of gross domestic product, improvement of the country's balance of payments structure, and is a significant factor in overall economic development. Given the accelerated growth and development of tourism and its increasingly important role in the global market, it has a major impact on other related industries, both directly and indirectly. The aim of the paper is to point out the financial effects of tourism as one of the fastest growing industries on the world economy.
\end{abstract}

Keywords: Tourism, economy, development, world.

\section{INTRODUCTION}

Tn the last two decades, service industries have been rapidly developing and significantly participating in the overall economic structure, primarily in economically developed countries where service industries have become one of the most important drivers of economic development. Also, growth in the service industry is also present in developing countries, with the intensity of growth being weaker and with more differences than in developed countries. A number of factors have influenced the development of the service (tourism) industry, where comparatively modern technology influences the expansion of the tourism sector's offerings and changes its structure. The development of information technology has changed the relationship between services and consumers, first of all in banking and insurance, in tourism, transport and other activities (Čačić, 2013).

The economic growth and development of one country, as well as its ability to reduce the economic gap with other countries, depends on the ways and effectiveness of solving economic problems such as unemployment, balance of payments deficits, fiscal and monetary macroeconomic imbalances. In this regard, the tourism sector is considered a key factor (Kum, Aslan, \& Gungor, 2015).

The tourism industry is one of the fastest growing branches of the world. It is also considered to be one of the world's leading industries with its economic activities providing goods and services to visitors and connectivity with other industries such as transportation, hotels, services and the entertainment industry (Gul, 2013).

It is very important to emphasize that tourism generates so-called ,invisible exports', that is, the income of a country from foreign tourism in it and the so-called ,invisible imports', or expenditures of that country from foreign tourism in it. Accordingly, tourism as an economic ac-

Faculty of Economics in Subotica, University of Novi Sad, Segedinski put 9-11, 24000 Subotica, Serbia 
tivity has a significant impact on the foreign trade of specific countries, as well as an impact on economic developments in those countries. As revenues and expenditures are very significant for economically developed countries, their importance is particularly emphasized in countries with less developed industries, as they often have better and more diverse tourism development resources and cheap labor. Both groups of countries include tourist-known countries that differ in their degree of economic development (Unković \& Zečević, 2011). Based on the above hypothesis, the research reads: tourism activity has a positive and significant impact on the entire world economy. The subject of the research is the analysis of the impact of tourism on economic indicators such as total income, GDP, investment capital and employment.

\section{LITERATURE REVIEW}

Tourism in all modern economies has one of the key roles in achieving certain macroeconomic goals such as: GDP, employment, development of less developed areas, positive impact on the country's balance of payments through exports and foreign direct investment. The participation of the economy directly and indirectly related to tourism in GDP is many times higher than the share of tourism of the branch in GDP, which speaks in favor of the positive effect of tourism on the overall economy of a country (Petković, Zečević, \& Pinto, 2011).

Important means of economic development in terms of its impact on GDP countries, increase in employment, repair of current budget deficits, increase in international foreign exchange income, both in developing and developed countries of the world is tourism. Covering many areas such as accommodation, logistics, food and beverage services, promotions and marketing, tourism is one of the fastest growing and expanding sectors in the world economy, allowing capital and people to move between countries (Collu, Altin, Akgun, \& Eyduran, 2018).

As a dynamic category, tourism is constantly evolving all over the world. The development of tourism was reflected on the one hand by offering new forms of travel, new destinations and arrangements, while on the other, it created a need for new forms of organization, greater resources and new strategies. It is present in all countries of the world, but the differences are reflected in the scope and effects of realization. The data so far show that tourism is developed in countries that have better economic indicators such as: living standards of the population, national income, employment, balance of payments, infrastructure and more (Nedeljković, Jovanović, \& Đokić, 2013).

Tourism is primarily an industry defined by demand, unlike most industries that are defined by production, in national accounts such as agriculture and production. The extent of the tourism industry is in fact determined by its consumers at the time of consumption (Smeral, 2006). It is a significant source of foreign exchange, with foreign exchange inflows being one of the most important items in the balance of payments and a very significant factor in the overall economic development of countries. An interesting fact is that this inflow of foreign currency is not realized by export of goods across the national border of the country (,,invisible exports"), where instead of the classic export of goods, it is ,imported" by a consumer (tourist) whose consumption in the destination is the basis of foreign exchange inflow (Bošković, 2009).

This type of export has certain advantages over classic exports of goods and services:

- The natural, cultural and social attractiveness of a country cannot be the subject of international trade but can be valorized through tourism, affecting tourism demand and indirectly ,sold“ in the tourism market in the form of higher prices for tourism products, 
- Certain types of products are sold to foreign tourists who have visited the country automatically "exported" at higher prices than they were traditionally exported (selling souvenirs, traditional drinks like wine),

- Exports through sales to foreign tourists result in high profits, not only because of the higher prices mentioned above, but also because costs are lower in this case, such as transport costs,

- Certain types of sensitive products sold to tourists in a given country can often fail to meet the criteria for international trade, such as agricultural products (Sharpley \& Telfer, 2004).

It is important to note that tourism, as a low-accumulation activity, does not quickly exert economic effects. Although tourism has achieved immeasurable effects in other countries in a relatively short period of time, its effects are largely long-term and have a delayed effect. The development of tourism in passive regions must be based on a detailed analysis of potentials, tourist markets and placement opportunities, and not only positive demographic shifts, but also establishment of harmony of economic complex and population complex as a development result (Devedžić, 2007).

A large number of publishing authors have studied the importance of tourism and have come to the conclusion that its importance is great both for developed economies, which base their development on a strong service sector, but also for underdeveloped countries, which through tourism development can look for a chance to reduce their poverty. Therefore, tourism provides employment for the whole range of occupations, from unskilled, to highly skilled workers. The development of tourism itself will have a positive impact on the development of other industries (directly or indirectly) through increased supply, which ultimately leads to increased employment. The current situation indicates that European countries play a major role in the global tourism market. However, some forecasts indicate that East Asia and Pacific may increase in the relatively near future with a decline in European countries' market share. The participation of transition countries in Europe is also expected to increase, given that they have great growth potential and are at the same time new and challenging tourism markets (Marjanović \& Đorđević, 2018).

In the last twenty years, due to the weeks of development of post-industrial society, there has been the emergence of a „new” type of tourist. A traditional visit to seaside tourist destinations is slowly changing the desire to visit pristine and sheltered parts of the world (Jovanović \& Živković, 2018).

In the last twenty years, the growth rate of tourism has been twice the rate of GDP growth, with tourism revenues outpacing health services, energy or agriculture. In many countries, it is among the three leading industries, achieving the largest or moving towards the highest volume of retail turnover and the highest employment (Theobald, 2004).

Initially, views on tourism came down to a predominant study of the economic consequences that tourism traffic brought to the hospitality, transportation and travel sectors and travel agencies. Subsequent research on tourism has indicated its impact on other economic and social activities, that is, on overall economic development. In this way, tourism is recognized, not only as a consequence of economic development, but also as a factor of economic development (Stanić \& Vujić, 2016). 
Like many industries, tourism was hit by a major economic crisis, but also due to the large effects of the crisis, tourism had a relatively high resilience. Data show that the tourism sector in some countries had a much faster recovery than individual national economies and was also the driver of economic recovery (Pjanić, Andrašić, \& Mirović, 2018).

Tourism has various economic impacts. Tourists contribute to sales, profit, tax revenue. Direct effects are realized in primary tourism sectors such as hotels, restaurants, public and private transport, entertainment and retail. Through secondary effects, tourism affects most sectors of the economy. The analysis of the economic impact of tourism activity usually focuses on changes in sales, revenue and employment in the region resulting from tourism activities. It is important to note that tourism impacts are not only economic, social or environmental, but there are many interconnected levels. Economic impacts are particularly evident in less developed countries. However, there seems to be a trade-off, where the positives outweigh the negatives. In general, the economic impact study has a more positive view, centered on the number of benefits that tourism can bring, although these benefits have been accompanied by numerous costs. There are several other categories of economic impact that are not usually covered by economic impact assessments, at least not directly:

- Price changes - tourism can sometimes increase the cost of lodging and retail prices in the area, often on a seasonal basis,

- Changes in the quality and quantity of goods and services - tourism can lead to a wider range of goods and services available in an area (or higher or lower quality than without tourism),

- Changes in property and other taxes - taxes to cover local service costs may be higher or lower in the presence of tourism activity. In some cases, taxes directly or indirectly levied on tourists may have the effect of reducing local taxes, and in some situations, locals may be more taxed to cover the additional costs of infrastructure and services,

- The economic dimensions of ,social impacts' and, environmental impacts', there are also economic consequences of most social and environmental impacts that are not usually addressed in economic impact analysis. They can be positive or negative (Ardahaey, 2011).

Nowadays, tourism is an industry with great economic impact that leads to certain social, cultural and physical consequences. In doing so, tourism, like other industries, is used as a national development ,tool". The development of tourism in one country has an impact on the country in both positive and negative ways. The given influences are mainly economic, social and cultural. Tourism is a commercial activity that has the effect of increasing employment, earning foreign exchange earnings and improving the living standards of people in the host country. Also, tourism enables the realization of certain infrastructure projects, socio-economic benefits for the local community, in terms of faster economic growth, more jobs, foreign exchange earnings, balanced development of weaker areas and higher government revenue. The development of tourism requires the support of the governments of countries and local communities and populations, with a balanced view of tourism development that processes the benefits and costs of tourism development (Fawaz \& Rehnama, 2014). It is very important to emphasize the importance of tourism for the public economy, especially at the local level (Dritsakis \& Athanasiadis, 2000).

With increasing tax revenue, the host country government is increasing investment in new infrastructure such as road construction, water supply and sewerage, communications networks, schools, sanitation and health deserts. However, additional expenditure on infrastructure re- 
sulting from the increase in tourist accommodation will require additional financial needs for water, roads, transport, health and energy (Lee \& Chang, 2008).

The claims of the economic importance of tourism provide greater respect for the business community, government officials and the general public. Community support is important for tourism because it is an activity that affects the entire community. Tourism businesses are heavily dependent on the business community, government and local community residents. The economic benefits and costs of tourism in one way or another affect almost all structures in one country and even in the region. Economic impact analyzes provide tangible assessments of these economic interdependencies and a better understanding of the role and importance of tourism in the region's economy.

Globalization affects all segments of political, cultural, social and economic life, with tourism being the best example of today's great impact of globalization. Given the accelerated growth and development of tourism and its increasingly important role in the entire global market, it has a major impact on other related industries, both directly and indirectly. Also, tourism is gaining important potential for development, given the fact that this commercial activity connects the sale of goods and services, and the characteristic of driving consumers to producers, not the other way around. The impact of tourism can also be seen in creating opportunities for small businesses to expand and develop their business activities, which, under other conditions, would not disrupt global supply chains. The growing economic role and impact of tourism is undoubtedly having a significant impact on the creation of gross domestic product (GDP), both directly and indirectly (Vukadinović, Damnjanović, \& Jovanović, 2017).

The effects of tourism on the economy are direct, indirect and induced effects. Direct effects are manifested as a direct result of tourism activities (tourism spending, employment in the tourism sector and taxes paid by tourism activities). Indirect effects are manifested through the impact of tourism activities on other economic sectors (hotels that buy goods from merchants or procure food from producers). Induced effects are changes in economic activity that result from households benefiting from the tourism sector (tourism employees paying tax or spending money on local goods and services). These impacts and the structure of the tourism sector determine the economic impact of the sector on a country (Lemma, 2014).

Tourism development has a significant impact on improving the standard of living as well as reducing poverty and developing social support for the region. Accordingly, a sustainable tourism industry requires the achievement of long-term integration of social and economic goals, leading to an awareness of the close link between these indicators in the development of tourism in the region. The economic impact of the potential contribution of different types of tourism includes: ethnic tourism, sports tourism, congress and exhibition tourism, festival tourism and cultural tourism, all explored as well (Dredge, 2004).

It is very important to emphasize the conditions under which tourism has a negative impact on the socio-economic sphere, such as terrorist attacks, political unrest and other conditions that negatively affect economic development. It can be concluded that the economic and social implications of tourism are very significant, for example, epidemic outbreaks, terrorist attacks, political events and others adversely affect economic development. The social and economic implications of tourism are obviously significant, but its environmental and policy implications should also be taken into account when assessing the overall impact of tourism on the sustainable development of the region (Dwyer, Forsyth, Spurr, \& VanHo, 2006). 
As one of the fastest growing industries, tourism has proven to be a significant source of economic prosperity. The key question that arises when considering the impact of tourism is that tourism is usually considered as a specific industry, while in most of the applied situations it shows the characteristics of a complex and structured economic activity characterized by a mixture of different industries (Socci, Ali, Ciaschini, Pretaroli, \& Severini, 2016).

In the European Union, tourism is a major economic activity that accounts for large consumer spending items and provides a significant source of revenue to government in many jurisdictions through related taxes. Tourism is at the heart of achieving an EU strategy to promote economic recovery and growth. It is not limited to activities that involve the accommodation of tourists, catering, entertainment, transportation of tourists, but tourism and its organization are closely linked to all the main functions, processes and procedures applied in various areas related to tourism as a system. In addition, the tourism industry includes the functions of planning, organizing, coordinating, training and monitoring-evaluation at all levels, both internationally, nationally, regionally and locally, with tourism being integrated into the functional whole of the economy (Simoni \& Mihai, 2012).

\section{RESEARCH METHODOLOGY}

Secondary research was applied in the paper. Of the basic methods of cognition, and for theoretical considerations of the subject of research, analytical-synthetic, inductive-deductive, method of abstraction and generalization were used. From the scientific methods, the content analysis method was used. Data from available literature, scientific and professional papers, the Internet and other sources were also used.

\section{ECONOMIC IMPACT OF TOURISM}

Tourism as a source of income is not easy to measure at least with any degree of accuracy. However, the most common method for estimating tourism revenue is to determine the „multiplier effect" in the destination. The inflow of money that tourists make through tourism spending is repeatedly transformed into different segments of the economy. Tourists first spend money at a local destination and that money is received by local tourism workers, vendors, hotels, etc. In this way, the money spent by tourists brings income many times higher than the original spending. This is called the „multiplier effect”.

The impact of tourism on unemployment is widespread in the economy, affecting almost all parts of services and other sectors. The tourism industry is a high-intensity service industry, and is therefore a valuable source of employment, employing far more people than the manufacturing industry. A large number of business firms such as hotels, motels, restaurants, transport agencies, travel agents, souvenir shops, taxi drivers are experiencing an economic boom. What is particularly important with the tourism industry is the fact that it employs a large number of people with a wide range of jobs, ranging from unskilled to highly skilled workforce.

Not only developing countries but also some developed countries need to improve their balance of payments through tourism. Developing countries with a balance of payments deficit find it advantageous to receive foreign tourists to make up for the negative trade balance. Thus, the tourism industry can play an important role in the economic development of each country. It helps to improve the poor balance of payments of the countries as the tourism industry is the second largest exporting industry. 
The economic importance of tourism in a national economy is also reflected in its contribution to infrastructure development. The increase in tourist arrivals in a country leads to an increase in demand for infrastructure facilities. In this way, governments in many countries encourage the private sector to build tourism infrastructure. Tourism contributes to the even regional development of the country. Balanced regional development is an important factor for optimal, undisturbed and overall development. The tourism industry can develop specific tourism areas in each district. Many types of taxes are included in goods and services related to tourists. All tourism earnings increase many economic activities in countries and these economic activities are a great source of taxable earnings for the governments of national economies. Equally important is the impact of tourism on the spread of education and literacy, helping us to expand our mental attitude by interacting with diverse people by learning their languages and culture (Zaei \& Zaei, 2013).

The tourism sector is probably the only service sector that provides concrete and quantified trading opportunities for all nations, regardless of their level of development. Also, there is a large uneven distribution of benefits in the tourism sector, which threatens the social, economic and environmental sustainability of tourism in some developing countries. For many developing countries, tourism is one of the pillars of their development process, as it is one of the dominant activities in the economy, while for others, especially in the islands and some small economies, it is the only source of foreign exchange and employment and therefore represents a platform for their economic development. For these reasons, it is very important that tourism planners must understand that these three concepts, environment, economy and society, are inextricably linked (Spanou, 2007).

There are three main methods of analysis that make it possible to calculate the economic impact of tourism: (Zuruba, Ionescua, \& Constantina, 2015)

- Analysis of Importance (Significance analysis) is based on considering the size and structure of the tourism sector within national accounts, taking into account the consumption of residents as well as the population (tourists) from abroad. This method is about looking at and determining the tourism sector's share of consumption and gross domestic product (GDP). This method includes a large number of criteria for identifying the definition of visitors and tourists, the classification of tourism consumption, gross fixed capital formation in the tourism sector, ways of measuring the contribution to total tourism activity in gross domestic product (GDP) (Jakson, Houghton, Russel, \& Triandos, 2005),

- The second method of analysis - Impact Analysis - looks at the impact of money spent by foreign tourists on top of money returned from foreign tourism in domestic tourism to the economy of the region, whether it is a direct impact on hotels and restaurants, transport, retailers or an indirect impact on income and employment, taking into account the nature of the interaction between the tourism sector and other economic sectors. This method is specific because it can be used to analyze the overall impact of tourism on the economy of the country as a whole, or to analyze the impact of a particular type of tourist spending on a particular type of tourism activity.

- Cost-benefit analysis involves analyzing the feasibility and effectiveness of implementing tourism projects from the point of view of the entire community, with emphasis on measuring private and social benefits such as education and private and social costs, such as the environmental impact of tourism. Tourism is a sector with strong dynamics, in most countries it is on the increase compared to the global economic growth. 


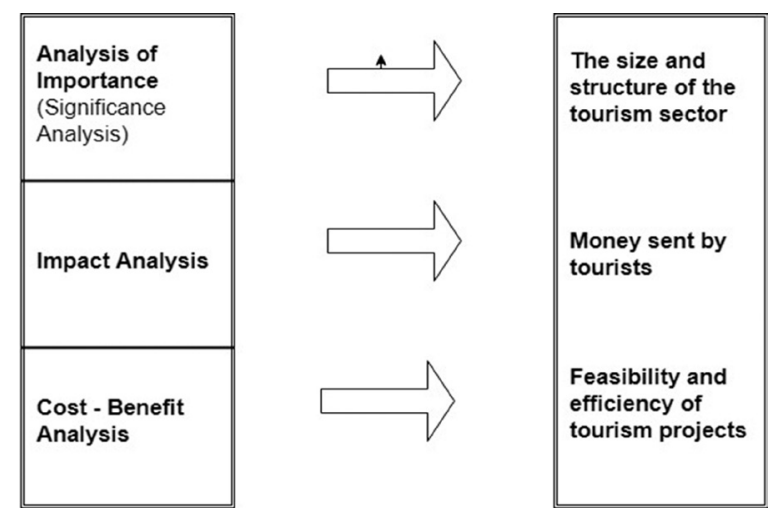

Figure 1. The three main analyses to measure the economic impact of tourism Source: (Zuruba, Ionescua, \& Constantina, 2015)

Accordingly, it is possible to classify tourism functions into two key groups: (Stanić \& Vujić, 2016)

\section{Economic functions:}

- Direct influence:

1. GDP,

2. Balance of payments,

3. Employment,

4. Development of underdeveloped areas.

- Indirect impact:

1. Infrastructure (construction),

2. Agriculture,

3. Industry.

- Multiplicative impact:

1. Consumption of foreign tourists,

2. Other influences.

\section{Non-economic functions:}

- Social function,

- Health function,

- Cultural function,

- Political function,

- Fun feature,

- Function regarding the defense of the country.

The tourism sector was hit during the period of economic crisis, but it recovered relatively quickly and recorded positive trends. Tourism is an important sector for the economy of the new member states of the European Union, representing about 12\% of their total GDP contribution, while the direct contribution of travel and tourism is about 5\% (ANA, 2017).

The European Union, as an example of a developed region, is an initiative in terms of international tourism development. Contemporary global trends have influenced the creation of various tourist integrations in the European Union, which with their creation and development, these tourist integrations want to preserve their specific values as motives for the future tourist flow (Gligorijević \& Petrović, 2009).

It is very important to emphasize the fact that the importance of the euro currency on tourism in the European Union. Certain studies suggest that adopting the euro could lead to an increase 
in tourism in the euro area and a diversion of tourism from abroad. In fact, reducing bilateral resistance to tourism between countries using the euro could reduce tourism between euro area countries and third countries (Karacayir, 2016).

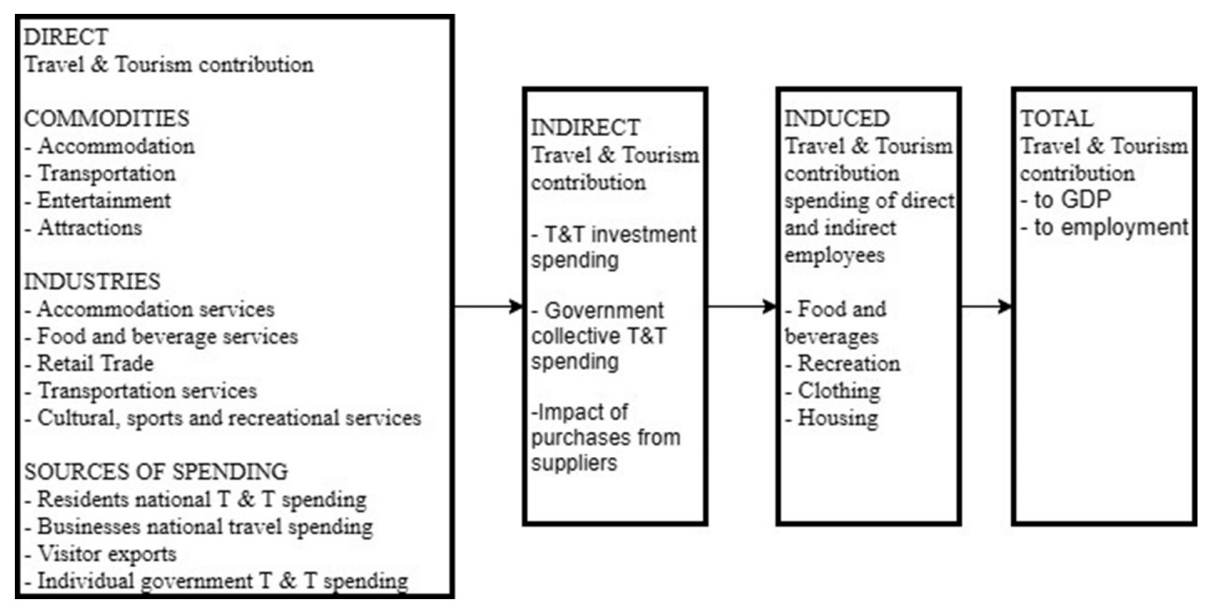

Figure 2. The economic contribution of travel \& tourism

Source: (WTTC, 2019)

The specificity of tourism is reflected in the fact that it enables the consumer to reach the producer and not vice versa, with each sale of services and goods to foreign tourists having a significant positive effect, especially on smaller companies, which, due to their modest financial capabilities, could not be part of the global supply chain. Apart from the direct and indirect effects of tourism on the economy, there are also positive and negative effects of tourism.

In addition to the stated positive economic effects of tourism, it should be emphasized that tourism has certain negative effects. First of all, tourism can lead to a fall in traditional employment and seasonal unemployment. A large number of companies and companies buy large quantities of goods during the tourist season and there is an increase in the prices of the given goods. The traditional decline in tourism employment implies the relocation of labor from certain industries such as agriculture, forestry, fisheries and mining to tourism services. Developing countries that want to enhance the tourism sector in order to increase foreign exchange inflows have the stated problem of retaining workforce in primary industries. Seasonal unemployment in destinations that are inactive during the year can be a big problem for some countries, which puts additional strain on local and state resources. The high number of tourists in peak tourist season causes an increase in demand for goods and services, which in turn increases the prices of products and services, which can burden the local population by paying higher prices for food, drinks, entertainment, etc. (Kusluvan \& Karamustafa, 2001).

Based on the available data presented in Table 2, it can be concluded that international tourism revenue globally increased from $\$ 1.221$ billion in 2015 to $\$ 1.245$ billion in 2016, an increase of $2.6 \%$. The same trend continued in 2017, when total international tourism revenue was $\$ 1.340$ billion, an increase of $4.9 \%$ over the previous year. The same moment was observed in economically developed countries, where tourism revenues amounted to $\$ 799$ billion in 2015, to grow to $\$ 814$ billion in 2016, representing a growth rate of $1.9 \%$. In 2017, tourism revenue in economically developed countries totaled $\$ 870$ billion, up 4.2\% from a year earlier. Also, developing economies are experiencing an upward trend in tourism revenue. In 2015, tourism revenues in developing economies totaled $\$ 423$ billion, rising to $\$ 431$ billion in 2016, an increase of 3.9\%. 
The same trend continued in 2017, when tourism revenues totaled $\$ 470$ billion, an increase of $6.2 \%$. Regionally, there is also an increase in tourism revenue. In Europe, revenues amounted to $\$ 468$ billion in 2015 , to grow by just $1.7 \%$ over the next year. However, as early as 2017 , revenue rose to $\$ 519.2$ billion, up 8\% from the previous year. The Asian and Pacific region generated \$ 355.6 billion in tourism revenue in 2015, and in 2016 revenue grew to $\$ 370.8$ billion, an increase of $4.1 \%$. In 2017, revenue grew to $\$ 389.6$ billion, up $2.6 \%$ from a year earlier. Tourism revenue in the Americas totaled $\$ 307.3$ billion in 2015 and $\$ 313.7$ billion in the non-financial year, an increase of 2.3\%. In 2017, revenues were $\$ 326.2$ billion, an increase of just $1.3 \%$. The African continent generates 32.2 billion in tourism revenue in 2015, and next year revenues amount to $\$$ 33 billion, an increase of $4.9 \%$. Revenue growth was also achieved in 2017, when they amounted to $\$ 37.3$ billion, an increase of $8 \%$. The Middle East generates $\$ 58$ billion in tourism revenue in 2015 to increase that $\$ 1$ billion and 1\% percent in the non-standard year. In 2017, revenues totaled $\$ 67.7$ billion and grew by $12.8 \%$.

Table 1. Possible effects of tourism

\begin{tabular}{|l|l|}
\hline \multicolumn{1}{|c|}{ Positive effects } & \multicolumn{1}{c|}{ Negative effects } \\
\hline - Increase of revenues/increase of living standard & - Big dependence on tourism \\
- Employment opportunities & - Increased living costs-accommodation, food and ser- \\
- Improvement of infrastructure in tourism & vices \\
- Increase of tax income & Pollution and traffic congestion \\
- Raising awareness and increasing resources for cul- & - Harmful effects on cultural and natural Heritage \\
tural and natural heritage & - Sensitivity of business cycles and changes of business \\
- Capital inflows & attitude \\
- Transfer of professionalism and managerial skills & - Little control of tourism development \\
- Market connections & - Unacceptable form and volume of development \\
- Visible effects for local entrepreneurs & - Invasion of open spaces \\
\hline
\end{tabular}

Source: (Kumar, Hussain, \& Kannan, 2015)

Table 2. Development of international tourist-financial indicators

\begin{tabular}{|c|c|c|c|c|c|c|c|}
\hline \multirow[b]{2}{*}{ Year } & \multicolumn{2}{|c|}{$\begin{array}{l}\text { International tourism } \\
\text { revenues ( } \% \text { of change) }\end{array}$} & \multirow{2}{*}{$\begin{array}{c}\begin{array}{c}\text { Market } \\
\text { share (\%) }\end{array} \\
2017 \\
\end{array}$} & \multicolumn{4}{|c|}{ Revenues (USD) (billion) per tourist } \\
\hline & $16 / 15$ & $17 / 16$ & & 2015 & 2016 & 2017 & $2018 *$ \\
\hline World & 2.6 & 4.9 & 100 & 1,221 & 1,245 & 1,340 & 1,010 \\
\hline $\begin{array}{l}\text { Developed } \\
\text { economies }\end{array}$ & 1.9 & 4.2 & 65 & 799 & 814 & 870 & 1,200 \\
\hline $\begin{array}{l}\text { Developing } \\
\text { economies }\end{array}$ & 3.9 & 6.2 & 35 & 423 & 431 & 470 & 790 \\
\hline \multicolumn{8}{|c|}{ Regions by UNWTO: } \\
\hline Europe & 1.7 & 8.0 & 39 & 468.0 & 468.1 & 519.2 & 770 \\
\hline $\begin{array}{l}\text { Asia and } \\
\text { the Pacific }\end{array}$ & 4.1 & 2.6 & 29 & 355.6 & 370.8 & 389.6 & 1,210 \\
\hline America & 2.3 & 1.3 & 24 & 307.3 & 313.7 & 326.2 & 1,560 \\
\hline Africa & 4.9 & 8.0 & 3 & 32.2 & 33.0 & 37.3 & 600 \\
\hline $\begin{array}{l}\text { Middle } \\
\text { East }\end{array}$ & 1.0 & 12.8 & 5 & 58.0 & 59.0 & 67.7 & 1,160 \\
\hline
\end{tabular}

Source: (UNWTO, 2019), (WTTC, 2019), (World Economic Forum, 2019)

*Provisional data

From Table 3, it can be seen that the direct contribution of travel and tourism to GDP grew year by year in the observed period. The value of this indicator amounted to $\$ 2.420$ billion in 2015 , to $\$ 2.517$ billion in the next year and an increase of $4 \%$. In 2017 , the value of the direct contribution of travel and tourism was $\$ 2.646$ billion, an increase of $5.1 \%$ over the previous year. The 
upward trend in this indicator continued in 2018 when its value was $\$ 2.750$ billion, an increase of $3.9 \%$ over the previous year. At the same time, the share of this indicator in GDP has steadily increased over the observed period from $3 \%$ in 2015 , then $3.1 \%$ in $2016,3.2 \%$ in 2017 , with identical growth in 2018. The overall impact of this indicator is growing year on year. In 2015, the value of this indicator was US \$ 7.772 billion, with a 10\% share of GDP. Next year, the value of this indicator is $\$ 8.100$ billion, an increase of $4.2 \%$ with a concurrent GDP share of $10.2 \%$. The upward trend continued in 2017, when this indicator amounted to $\$ 8.502$ billion, which is a growth of $5 \%$ and a slight increase in the share of GDP, at $10.4 \%$. Also, in 2018, there is a fall in the value of this indicator, amounting to $\$ 8.811$ billion, an increase of $3.6 \%$ compared to the previous year, with an identical percentage share in GDP of $10.4 \%$.

Table 3. Travel \& tourism impact on GDP (in billion US dollars)

\begin{tabular}{|l|c|c|c|c|}
\cline { 2 - 4 } \multicolumn{1}{l|}{} & $\mathbf{2 0 1 5}$ & $\mathbf{2 0 1 6}$ & $\mathbf{2 0 1 7}$ & $\mathbf{2 0 1 8}$ \\
\hline $\begin{array}{l}\text { Direct contribution of Travel \& } \\
\text { Tourism to GDP }\end{array}$ & 2,420 & 2,517 & 2,646 & 2,750 \\
\hline \% of whole economy GDP & $3 \%$ & $3.1 \%$ & $3.2 \%$ & $3.2 \%$ \\
\hline $\begin{array}{l}\text { Growth direct contribution of Travel } \\
\text { \& Tourism }\end{array}$ & $5.8 \%$ & $4 \%$ & $5.1 \%$ & $3.9 \%$ \\
\hline $\begin{array}{l}\text { Total contribution of Travel \& } \\
\text { Tourism of GDP }\end{array}$ & 7,772 & 8,100 & 8,502 & 8,811 \\
\hline$\%$ of whole economy GDP & $10 \%$ & $10.2 \%$ & $10.4 \%$ & $10.4 \%$ \\
\hline $\begin{array}{l}\text { Growth total contribution of Travel \& } \\
\text { Tourism of GDP }\end{array}$ & $5.2 \%$ & $4.2 \%$ & $5 \%$ & $3.6 \%$ \\
\hline
\end{tabular}

Source: (UNWTO, 2019), (WTTC, 2019), (World Economic Forum, 2019)

As noted above, the tourism sector is a rapidly growing industry with an increasing share of GDP, while employing a large number of skilled and low-skilled labor. The following table shows that the direct impact of tourism and travel on total employment has steadily increased over the observed period. In 2015, the direct number of employees amounted to 115,297 thousand, and that number would increase to 117,336 thousand in the following year, with a growth rate of $1.8 \%$, whereby the share of this indicator in total employment also increased from $2 \%$ to $2.9 \%$. In 2017, this indicator will increase, at 119,627 thousand, with a growth rate of $2 \%$ compared to the previous year, while the share of this indicator in the total employment of $3.8 \%$. In the following year, this indicator will increase, amounting to 122,891 thousand, with a percentage increase of $2.7 \%$ and the same percentage share in employment of $3.8 \%$. Analyzing total employment, it can be seen that it has been constantly growing throughout the observed period. In 2015, it amounted to 296,101 thousand, and the following year this indicator would amount to 303,431 thousand, with an increase of $2.5 \%$ and a simultaneous share in the total employment of 9.7\%. Growth was also achieved in 2017 when this indicator amounted to 311,703 thousand, growing at a rate of $2.7 \%$, with a simultaneous increase in the percentage share in total employment, where it amounted to $9.9 \%$. In the last year of the observed period, there is also an increase in the value of this indicator, whose value amounted to 318,811 thousand with a growth rate of $2.3 \%$ compared to the previous year and a slight increase in the share in total employment of $0.1 \%$, with participation of was $10 \%$.

In the aftermath of the global economic crisis that has hit all economies, investment activity globally has seen considerable fluctuations. However, in the tourism sector, the situation is far more favorable. 
Table 4. Impact of Travel \& tourism employment on the overall economy employment (in thousands)

\begin{tabular}{|l|c|c|c|c|}
\cline { 2 - 5 } \multicolumn{1}{c|}{} & $\mathbf{2 0 1 5}$ & $\mathbf{2 0 1 6}$ & $\mathbf{2 0 1 7}$ & $\mathbf{2 0 1 8}$ \\
\hline $\begin{array}{l}\text { Direct contribution of travel \& } \\
\text { tourism to employment }\end{array}$ & 115,297 & 117,336 & 119,627 & 122,891 \\
\hline$\%$ of whole economy employment & $2 \%$ & $2.9 \%$ & $3.8 \%$ & $3.8 \%$ \\
\hline $\begin{array}{l}\text { Growth direct contribution of travel } \\
\text { \& tourism to employment }\end{array}$ & $2.7 \%$ & $1.8 \%$ & $2 \%$ & $2.7 \%$ \\
\hline $\begin{array}{l}\text { Total contribution of travel \& tourism } \\
\text { to employment }\end{array}$ & 296,101 & 303,431 & 311,703 & 318,811 \\
\hline$\%$ of whole economy employment & $9.5 \%$ & $9.7 \%$ & $9.9 \%$ & $10 \%$ \\
\hline $\begin{array}{l}\text { Growth total contribution of travel \& } \\
\text { tourism to employment }\end{array}$ & $3.2 \%$ & $2.5 \%$ & $2.7 \%$ & $2.3 \%$ \\
\hline
\end{tabular}

Source: (UNWTO, 2019), (WTTC, 2019), (World Economic Forum, 2019)

Table 5. Capital investment in travel \& tourism (in billion US dollars)

\begin{tabular}{|l|c|c|c|c|}
\cline { 2 - 5 } \multicolumn{1}{c|}{} & $\mathbf{2 0 1 5}$ & $\mathbf{2 0 1 6}$ & $\mathbf{2 0 1 7}$ & $\mathbf{2 0 1 8}$ \\
\hline $\begin{array}{l}\text { Capital investment in travel \& } \\
\text { tourism }\end{array}$ & 824.2 & 850.5 & 905.0 & 940,9 \\
\hline \% of whole economy investment & $2.3 \%$ & $3.1 \%$ & $4.8 \%$ & $4.4 \%$ \\
\hline $\begin{array}{l}\text { Growth capital investment in travel \& } \\
\text { tourism }\end{array}$ & $5.1 \%$ & $3.2 \%$ & $6.4 \%$ & $4 \%$ \\
\hline
\end{tabular}

Source: (UNWTO, 2019), (WTTC, 2019), (World Economic Forum, 2019)

From Table 5, it can be seen that investments in the tourism sector have been growing year by year, where in 2015 they amounted to $\$ 824.5$ billion and in 2016 this amounted to $\$ 850.5$ billion, with an increase of 3.2\% in compared to the previous year and 3.1\% share in total investments. The upward trend continued in 2017, when tourism investments totaled $\$ 905$ billion, up $6.4 \%$ from the previous year and $4.8 \%$ in total investment, and in the last year of the observed period there has been an increase in investments in tourism, where their value amounts to $\$$ 940.9 billion, with an increase compared to the previous year of $4 \%$ and at the same time a share in total investments of $4.4 \%$.

\section{FUTURE RESEARCH DIRECTIONS}

In addition to all the aforementioned economic advantages of tourism, which are undoubtedly significant for all countries of the world, some future research should be based on a more detailed analysis of the negative effects of tourism, not only from the economic but also from other aspects. Due to the globalization process, many countries and travel agencies are taking advantage of the economic benefits of tourism to justify their existing and promotional budget. Also, some research should be based on a consideration of seasonal problems of tourism employment / unemployment, especially in developing countries, as well as equal employment in the tourism industry and other primary industries. Particular attention should also be paid to the potential dangers of terrorist attacks and natural disasters, which, in addition to economic losses, endanger the lives of tourists.

\section{CONCLUSION}

No matter the many problems caused by the global economic crisis that almost all industries have encountered, the tourism industry has shown relatively enviable resilience to the effects of the crisis with a much faster recovery of this industry relative to individual national economies. The strong development of tourism in the last two decades has also influenced the strengthening of 
all other industries directly and indirectly related to the tourism industry. The conducted research indicates significant economic effects of tourism on the entire world economy. Analyzing the impact of tourism, it can be concluded that the tourism sector is increasing its share of GDP as a whole. Also, the tourism industry employs a growing number of skilled and low-skilled workforce year after year, which is registering an increase and share in overall employment. There is also an increase in capital investments in the tourism industry from year to year in the tourism sector, as well as a share in total capital investments. All of the above indicates that the tourism industry can be considered very significant for the overall global economy. All the world's regions have seen an increase in the total number of tourists, where the European continent has been the most popular tourist destination so far, but lately other destinations have also seen an increase in the number of tourists, where the Asian region is becoming more popular. It is particularly important to point out that developing countries are also achieving enviable results in the tourism industry, which has become one of the key tools for improving the overall economic situation. In addition to all the economic direct and indirect benefits, the tourism industry has certain negative effects that must also be given considerable attention. It is evident that the tourism industry is becoming one of the key drivers of growth and development of the entire global economy.

\section{REFERENCES}

Ana, M. (2017, August 26). Tourism industry in the new Europe: trends, policies and challenges. Proceedings of the 11th International Conference on Business Excellence: https:// content.sciendo.com/view/journals/picbe/11/1/article-p493.xml

Ardahaey, F. (2011). Economic Impacts of Tourism Industry. International Journal of Business and Management, 6(8), 206-215.

Bošković, T. (2009). Turizam kao faktor privrednog razvoja. Škola biznisa, 2, 23-28.

Čačić, K. (2013). Poslovanje hotelskih preduzeća, Beograd: Univerzitet Singidunum.

Collu, D., Altin, A. Y., Akgun, L., \& Eyduran, E. (2018). Assessment of factors affecting financial performance of tourism companies in best by means of data mining algorithms in financial ratios. U Management Tools and Economy of Tourism Sector in Present Era: 3rd international thematic monograph: thematic proceedings (pp. 425-440). Belgrade: Association of Economists and Managers of the Balkans in cooperation with the Faculty of Tourism and Hospitality, Ohrid, Macedonia.

Devedžić, M. (2007). Prilog izučavanju uticaja turizma na demografski razvitak. Stanovništvo. 2, 63-79.

Dredge, D. (2004). Development, economy and culture: Cultural heritage tourism planning, Liangzhu, China. Asia Pacific Journal of Tourism Research, 9(4), 405-422.

Dritsakis, N., \& Athanasiadis, S. (2000). An econometric model of tourist demand: The case of Greece. Journal of Hospitality \& Leisure Marketing, 7(2), 39-49.

Dwyer, L., Forsyth, P., Spurr, R., \& VanHo, T. (2006). Economic effects of the world tourism crisis on Australia. Dwyer, L., Forsyth, P., Spurr, R., VanHo, T., (2006). Tourism Economics, 12(2), 171-186.

Fawaz, F., \& Rehnama, M. (2014). An empirical refinement of the relationship between tourism and economic growth. An International Journal of Tourism and Hospitality Research, 25(3), 1-14.

Gligorijević, Ž., \& Petrović, J. (2009). Tourism - factor of integration and development of European Continent. Facta Universitatis, Series: Economics and Organization, 6(2), 123-130.

Gul, H. (2013). Economic impacts of an increase in the Foreign tourism receipts: a sam-based income Multiplier analysis for Turkey. Advances in Hospitality and Tourism Research, $1(1), 17-36$. 
Jakson, J., Houghton, M., Russel, R., \& Triandos, P. (2005). Innovations in Measuring Economic Impacts of Regional Festivals: A Do-It-Yourself Kit. Journal of Travel Research, 43(4), 360-367.

Jovanović, L., \& Živković, D. (2018). Sustainable development of tourism by diversification of touristic portfolio. U Modern Management Tools and Economy of Tourism Sector in Present Era: 3rd international thematic monograph: thematic proceedings (pp. 205-219). Belgrade: Association of Economists and Managers of the Balkans in cooperation with the Faculty of Tourism and Hospitality, Ohrid, Macedonia.

Karacayir, E. (2016). The relationship between foreign direct investment and intra industry trade: an empirical analysis on Turkey and EU (15) countries. 2 International Conference on Applied Economics and Finance (pp. 79-88). North Cyprus: Girne American University.

Kum, H., Aslan, A., \& Gungor, M. (2015). Tourism and Economic Growth: The Case of Next11 Countries. International Journal of Economics and Financial Issues, 5(4), 1075-1081.

Kumar, J., Hussain, K., \& Kannan, S. (2015). Positive vs negative economic impacts of tourism development: a review of economic impact studies. Developments of the new tourism paradigm in the Asia Pacific Region (pp. 405-413). Kuala Lumpur: Malaysia.

Kusluvan, S., \& Karamustafa, K. (2001). Multinational Hotel Development in Developing Countries: An Exploratory Analysis of Critical Policy Issues. International Journal of Tourism Research, 3(3), 179-197.

Lee, C., \& Chang, C. (2008). Tourism development and economic growth: A closer look at panels. Tourism Management 29, 180-192.

Lemma, A. (2014, July). Tourism Impacts Evidence of Impacts on employment, gender, income, economic and private sector professional evidence and applied knowledge services. Tourism Impacts - Gov.uk: https://assets.publishing.service.gov.uk/media/57a089f2ed915d622c000495/Tourism_Impacts_employment gender_income_A_Lemma.pdf

Marjanović, V., \& Đorđević, D. (2018). Globalizacija in turizem. Revija za ekonomske in poslovne vede, 5(1), 3-21.

Nedeljković, O., Jovanović, R., \& Đokić, M. (2013). Trendovi razvoja i uticaj globalizacije na turizam. Economy and Market Communication Review, 3(1), 73-86.

Petković, G., Zečević, B., \& Pinto, R. (2011). Turizam kao deo nacionalne ekonomije. Ekonomika preduzeća, 1(2), 89-97.

Pjanić, M., Andrašić, J., \& Mirović, V. (2018). Analysis of financial effects of tourism on economy of Serbia. U Modern Management Tools and Economy of Tourism Sector in Present Era: 3rd international thematic monograph: thematic proceedings (pp. 115-128). Belgrade: Association of Economists and Managers of the Balkans in cooperation with the Faculty of Tourism and Hospitality, Ohrid, Macedonia.

Sharpley, R., \& Telfer, D. (2004). Tourism and development-Concepts and Issues. Bristol: Channel View Publications / Multilingual Matters.

Simoni, S., \& Mihai, D. (2012). Tourism Organization and Coordination in Australia and the Managerial Strategy for Tourism Development. Simoni, Journal of Knowledge Management, Economics and Information Technology, 5, 1-16.

Smeral, E. (2006). Tourism Satellite Accounts: A Critical Assessment. Journal of Travel Research, 45(1), 92-98.

Socci, C., Ali, Y., Ciaschini, M., Pretaroli, R., \& Severini, F. (2016). Estimating the economic impact of tourism industry through the MM approach. Economic Sciences, 9(2), 127-152.

Spanou, E. (2007). The Impact of Tourism on the Sociocultural Structure of Cyprus. Tourismos: An International Multidisciplinary Journal of Tourism, 2(1), 145-162. 
Stanić, M., \& Vujić, T. (2016). Turizam kao faktor ekonomskog razvoja. Uloga i značaj turizma u privrednom rastu i razvoju. Bijeljina: Univerzitet Sinergija.

Theobald, W. (2004). Global tourism. Heinemann: Maryland Heights, MO: Elsevier Butterworth.

Unković, S., \& Zečević, B. (2011). Ekonomika turzma. Beograd: Centar za izdavačku delatnost Ekonomskog fakulteta u Beogradu.

UNWTO. (2019). World Tourism Barometar. Madrid: World Tourism Organization UNWTO.

Vukadinović, P., Damnjanović, A., \& Jovanović, Z. (2017). Position of tourism in global economy and its impact on GDP, employment and investments. Vojno delo, 4, 263-278.

World Economic Forum. (2019). The Travel \& Tourism Competitiveness Report 2019. Geneva: World Economic Forum.

WTTC (2019). Travel \& tourism economic impact 2019 World. London: World Travel \$ Tourism Council (WTTC).

Zaei, M., \& Zaei, M. (2013). The impacts of tourism industry on host community. European Journal of Tourism Hospitality and Research, 1(2), 12-21.

Zuruba, H., Ionescua, A., \& Constantina, V. (2015). Measuring the Economic Impact of Tourism in European Emerging Markets. Procedia Economics and Finance, 32, 95-102. 